\title{
EURIMBULA SITE 1, CURTIS COAST: SITE REPORT
}

\author{
SEAN ULM, MELISSA CARTER, JILL REID AND IAN LILLEY \\ Aboriginal and Torres Strait Islander Studies Unit, University of Queensland, \\ Brisbane, Queensland, 4072, Australia
}

\begin{abstract}
This site report presents an account of archaeological excavations undertaken at Eurimbula Site 1, a large open midden site complex located in Eurimbula National Park on the southern Curtis Coast, Central Queensland. Excavations yielded a cultural assemblage dominated by mud ark (Anadara trapezia) and commercial oyster (Saccostrea commercialis) and incorporating small quantities of stone artefacts, fish bone and charcoal. Densities of cultural material were found to decrease markedly with distance from the creek. Analyses of excavated material demonstrate extensive low intensity use of the site from at least c.3,200 cal BP to the historical period.
\end{abstract}

\section{Introduction}

This report details the results of limited test excavations undertaken at Eurimbula Site 1 between 1-6 April 1995. Excavations were conducted as part of the archaeological component of the Gooreng Gooreng Cultural Heritage Project (see Lilley and Ulm 1995, this volume).

The major objective of these excavations was to establish the connection between a prograding beach ridge formation and the deposition of cultural materials. In particular, data were collected to determine whether pre-European Aboriginal settlement patterns in the area were focussed on the estuary or the ocean beach; if the latter, the focus of settlement would be expected to move northward as beach ridges developed in that direction.

\section{Site Location and Description}

Eurimbula Site 1 is a large, stratified, midden complex intermittently exposed for some $2 \mathrm{~km}$ in a steep erosion face on the western bank of Round Hill Creek, which forms the eastern border of Eurimbula National Park (Figure 1). The approximate centrepoint of the site is located $4 \mathrm{~km}$ southwest of Round Hill Head and $34 \mathrm{~km}$ northeast of the town of Miriam Vale (Latitude: 24 ${ }^{\circ} 11^{\prime} 54^{\prime \prime}$; Longitude: 151 ${ }^{\circ} 51^{\prime} 34^{\prime \prime}$; Easting: 384166; Northing: 7323343). The site complex is registered as Queensland State File Numbers KE:A49-KE:A54 (inclusive) and Queensland Museum Number S864.

The site is approximately $2 \mathrm{~km}$ long (north-south) and up to $100 \mathrm{~m}$ wide (east-west), although surface exposures of shell are predominantly confined to a $50 \mathrm{~m}$-wide band adjacent to the creek. The site thus covers a minimum area of $100,000 \mathrm{~m}^{2}$. It is formed on and in a series of Holocene beach ridges and swales which run roughly parallel to the modern coastline. These features are formed by massive amounts of sandy sediments delivered to the coastal region by the rivers of Central Queensland. Hopley (1985:76-77) defines the area as a depositional coastline, characterized by a series of beach ridges trailing northwards from the northern side of almost every estuary of note (see also Rowland 1987). The beach ridges of Eurimbula are most likely swash-built, owing to the fact that they are oriented parallel to the ocean and occur in sets of 5-25 ridges (Tanner 1995:150).

The site was briefly described by Godwin (1990), who noted the archaeological potential of the site as a large stratified deposit not common in the area. Burke (1993) subsequently recorded the site complex in more detail during a heritage management study of the Curtis Coast, identifying 20 separate sites (CC112A, CC-113A, CC-114-CC-131) which were subsequently conflated into six sites when registered by the Queensland Environmental Protection Agency (KE:A49-KE:A54).

In the site cards lodged with the Queensland Environmental Protection Agency, Burke noted scattered mud ark and oyster shell and occasional whelks in various densities and locales along the creek bank. Material was noted within $40 \mathrm{~m}$ of the creek bank and up to $30 \mathrm{~cm}$ below the surface of the exposed erosion bank. A single stone artefact was recorded: a large, granitic core, which was thought to derive from the Round Hill Head headland.

\section{Excavation Aims and Methods}

The archaeological investigations at Eurimbula Site 1 were designed to complement earlier coastal work conducted at the Mort Creek Site Complex on Rodds Peninsula, located some $31 \mathrm{~km}$ northwest of Eurimbula Site 1 (see Carter 1997; Carter et al. this volume; Ulm and Lilley this volume).

A detailed examination of the surface of the entire site area adjacent to Round Hill Creek was undertaken before final selection of the areas to be excavated. This survey generally confirmed the results of previous studies, with scatters of surface shell and stone artefacts found to be concentrated at the southern end of the site. 


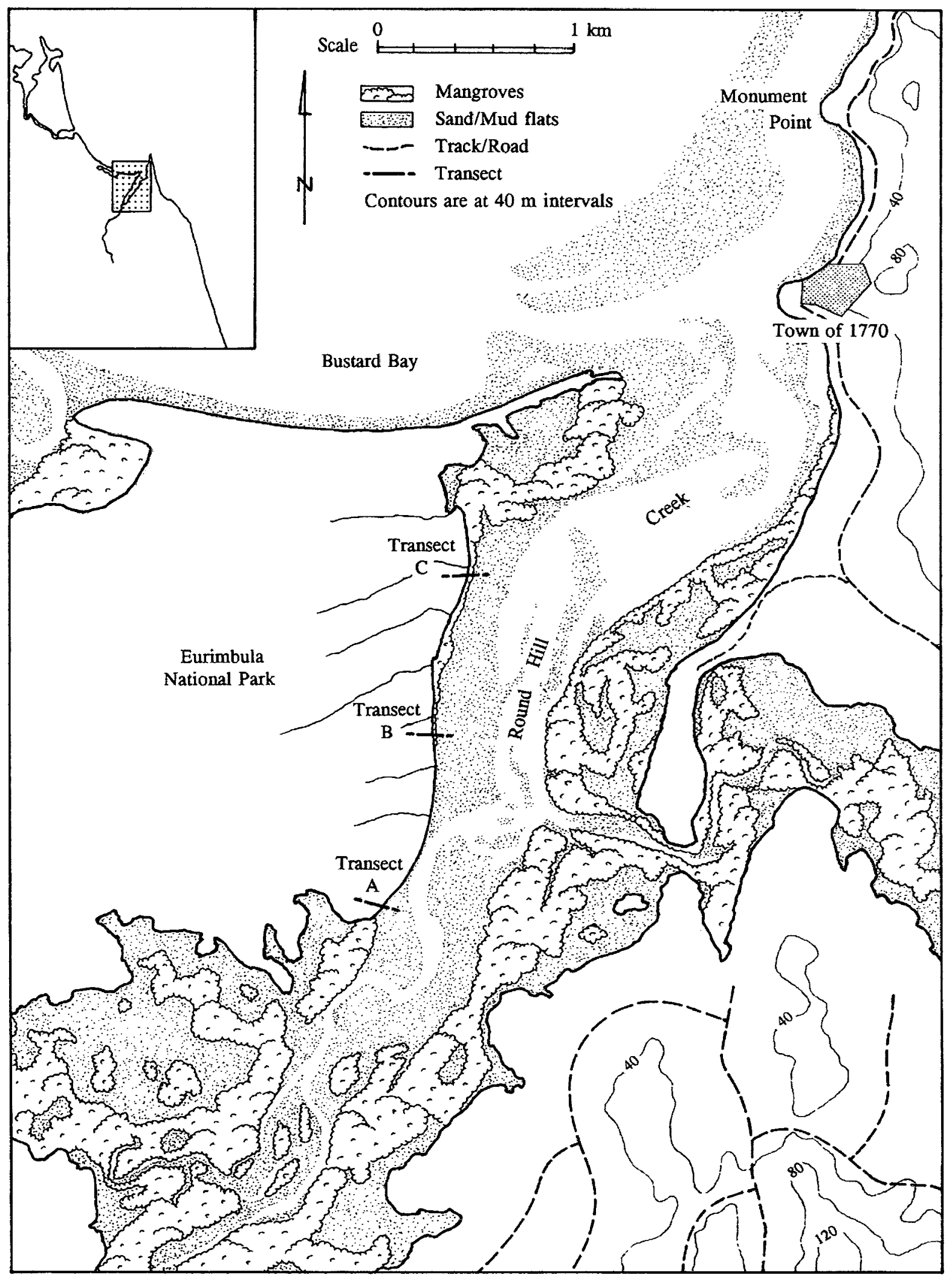

Figure 1. Round Hill Creek, showing the location of Transects A, B and C at Eurimbula Site 1. 


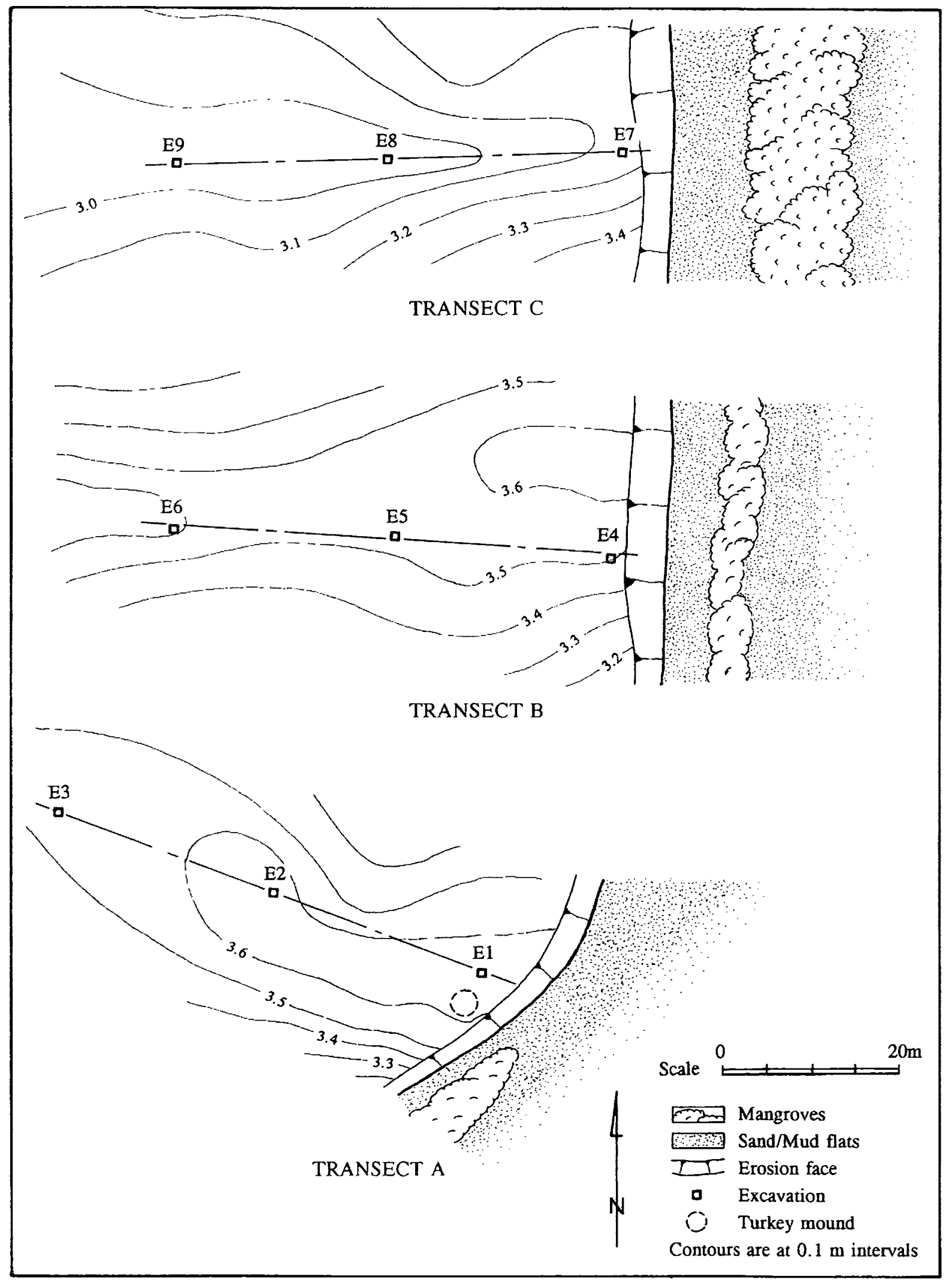

Figure 2. Location of test pits along Transects A, B and C at Eurimbula Site 1, showing topography in the immediate area of the transects. 
Detailed survey of the erosion bank revealed quantities of shell and occasional stone artefacts which had fallen out of the bank owing to undercutting wave action (Figure 14). Amongst the larger artefacts were several water-rounded microgranite hammerstones exhibiting impact-pitting. The closest known source of microgranite is Bustard Head, some $20 \mathrm{~km}$ to the northwest. Several large artefacts manufactured on pyroclastic rhyolite were also noted. Several of these display distinct bevelling along one margin and are roughly triangular in crosssection. These artefacts appear morphologically similar to the 'bevelled-pounders' found further south, which are functionally associated with processing of the root of the fern Blechnum indicum (Gillieson and Hall 1982; McNiven 1992; Richter 1994). Although pyroclastic rhyolite is available on the east bank of Round Hill Creek ( $1 \mathrm{~km}$ east), only two quarries have been identified: a minor extraction site on Round Hill Head $4 \mathrm{~km}$ to the northeast (Rowland 1987), and a massive quarry on the south bank of Middle Creek $11 \mathrm{~km}$ to the northwest (Reid 1998). Visibility away from creek margins was limited owing to dense vegetation cover, although erosion banks and clearings were examined in detail.

After survey had determined the general extent of the site complex, three excavation transects were selected for test excavation, towards the northern and southern ends and in the centre of the site complex respectively (Figure 1 ). In total, nine $50 \mathrm{~cm} \times 50 \mathrm{~cm}$ test pits were excavated at $25 \mathrm{~m}$ intervals along three transects placed approximately at right angles to the erosion face (Figure 2). The test pits were located across the site area in this way in an attempt to characterize the broad patterns of variation in subsurface deposits.

The general topography of the immediate area of each excavation transect was mapped using an autoset level and stadia rod. The $50 \mathrm{~cm} \times 50 \mathrm{~cm}$ pits were excavated in generally small $(2-5 \mathrm{~cm})$ arbitrary excavation units (XUs) within stratigraphic units (SUs). Elevations were recorded at the beginning and end of each excavation unit, using a local datum and a string line and level. Most excavated sediment was weighed in buckets on a tared spring-balance. All sediments were dry-sieved through $6 \mathrm{~mm}$ (coarse) and $3 \mathrm{~mm}$ (fine) nested screens. Some basal units, however, required wet-sieving owing to the high moisture content of the excavated sediments. This was conducted in the tidal creek adjacent to the site. All sieve residues were retained and bagged in the field, with the exception of large roots, which were weighed and discarded in the field. Sediment samples (c. 200g) were taken from each excavation unit from the material which passed through the $3 \mathrm{~mm}$ sieve. Coarse and fine sieve fractions from each excavation unit were bagged separately in the field but later combined for the purposes of laboratory analysis.

In addition to the excavations, a limited surface collection was made of a dense mud ark exposure adjacent to Square E7 to obtain a termination date for use of this area (Table 1) and a small bulk sample was taken from a discrete shell lens exposed in the west section of Square E1 to obtain samples for radiocarbon dating (Figure 3, 12-13).

\section{Stratigraphy \\ E1}

Square E1, located closest to the creek on Transect A, comprised three stratigraphic units (Figure 3). SUI consisted of dark brown humic soil containing many rootlets. Occasional scattered charcoal and mud ark (Anadara trapezia) and oyster (Saccostrea commercialis) valves were recovered from this unit. SUII consisted of loosely consolidated light browngrey sand with many small rootlets and included a discrete lens of mud ark in the southwest corner at 30$40 \mathrm{~cm}$ in depth. SUII, however, marked a stratigraphic change to a light-brown sandy matrix. Occasional stone artefacts were noted in this unit. Excavation terminated at a maximum depth of c. $70 \mathrm{~cm}$ below ground surface in culturally-sterile sediments.

\section{E2}

Square E2 contained three stratigraphic units (Figure 4). SUI comprised a dark brown humic layer containing large amounts of blocky charcoal. SUII represented a loosely consolidated, grey-white sand layer. Some shell occurred in this layer. The final SUIII consisted of a brown-yellow sand with small amounts of shell and rootlets.

\section{E3}

This test pit was the furthest from the creek along Transect $A$ and contained only two stratigraphic units (Figure 5). SUI consisted of a dark brown, sandy loam containing some organic material such as leaf and bark litter. SUII comprised light brown, loosely consolidated sand, with some shell, including land snail, charcoal and stone artefacts occurring throughout. Several cavities were encountered during excavation of SUII, presumably resulting from animal burrowing.

\section{E4}

Square E4, the test pit closest to the creek along Transect B, did not reveal any definable stratigraphic changes (Figure 6). This pit comprised light brown sand, with darker moist patches occurring throughout the deposit. Rootlets occur throughout with very little shell material recovered. Very sparse shell, charcoal, bone and stone artefacts present. 


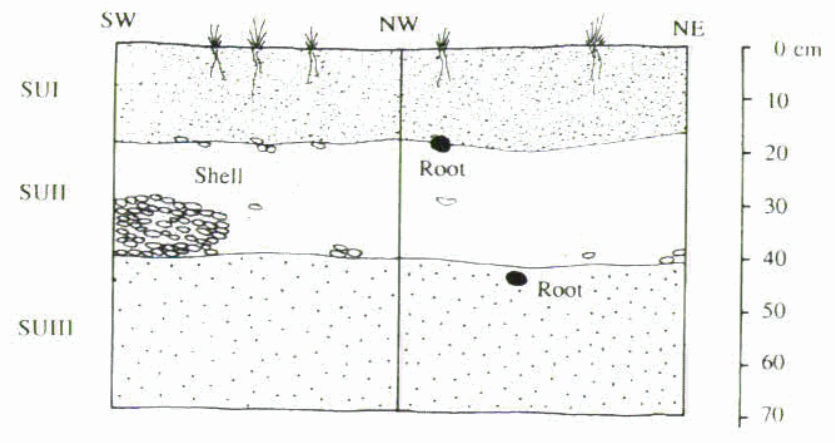

Figure 3. Northern and western stratigraphic profiles for Square E1.

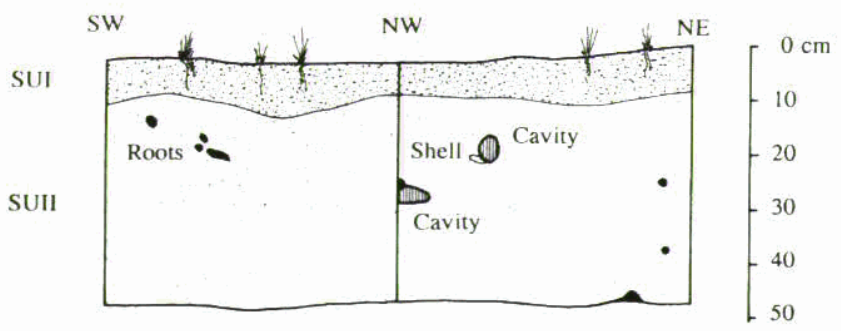

Figure 5. Northern and western stratigraphic profiles for Square E3.

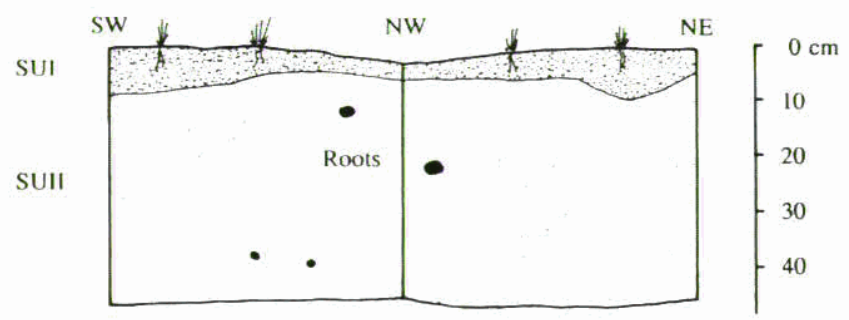

Figure 7. Northern and western stratigraphic profiles for Square E5.

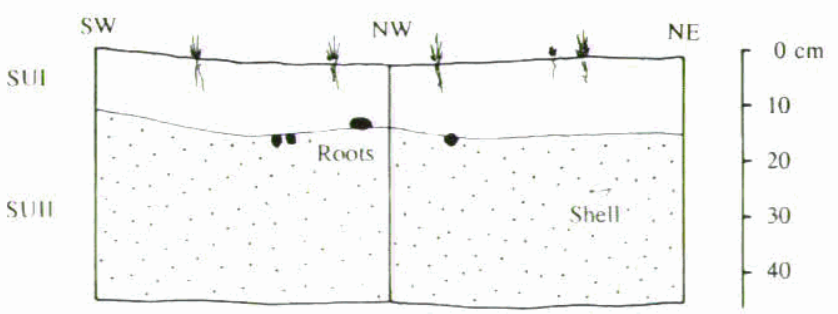

Figure 9. Northern and western stratigraphic profiles for Square E7.

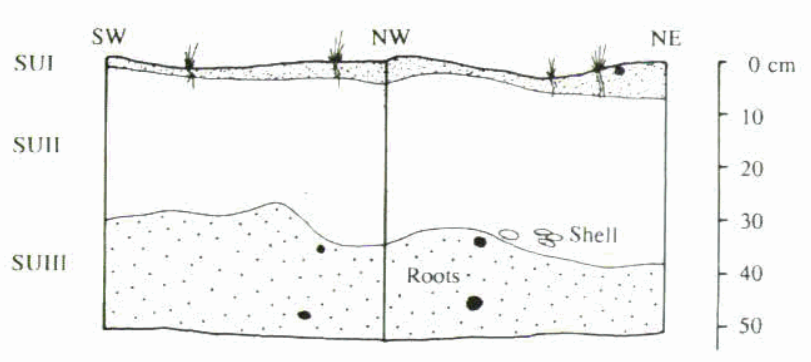

Figure 4. Northern and western stratigraphic profiles for Square E2.

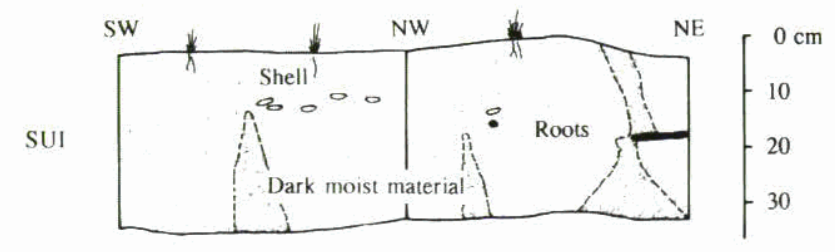

Figure 6. Northern and western stratigraphic profiles for Square $\mathbf{E 4}$.

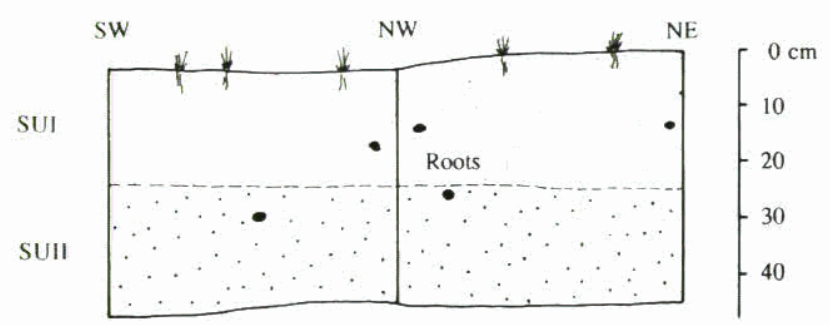

Figure 8. Northern and western stratigraphic profiles for Square E6.

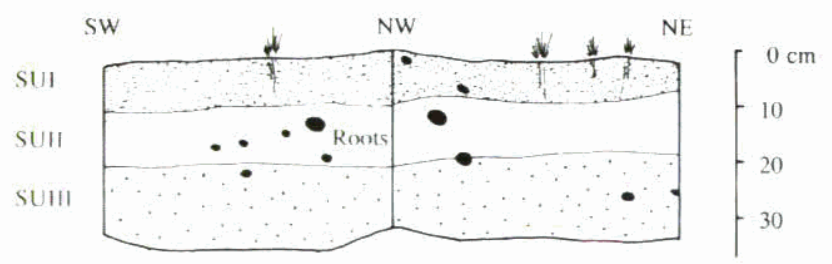

Figure 10. Northern and western stratigraphic profiles for Square E8. 


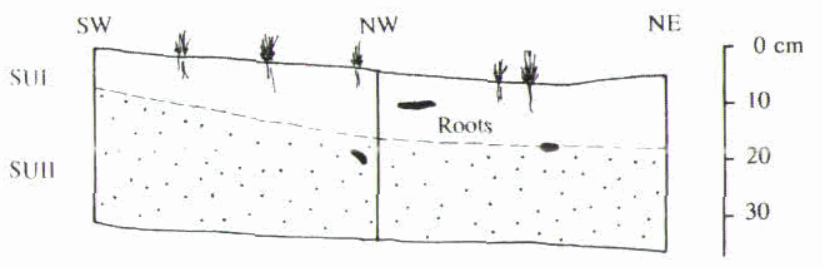

Figure 11. Northern and western stratigraphic profiles for Square E9.

\section{E5}

E5 contained two stratigraphic units (Figure 7). SUI comprised a thin, dark-brown humic layer containing many small and matted rootlets. Some blocky charcoal was also present in this unit. SUII consisted of a light brown sandy layer with very small amounts of shell and less charcoal than in the initial SU.

\section{E6}

Square E6 also comprised two stratigraphic units (Figure 8). SUI contained a fine, mottled grey sand, with decaying wood material and rootlets occurring throughout. SUII comprised a dark orangey-brown sand matrix with many roots still occurring. Charcoal is well represented throughout, but there is only very sparse shell material.

\section{E7}

E7, the excavation closest to the creek along Transect C, comprised two stratigraphic units (Figure 9). SUI consisted of a light brown sand with blocky charcoal, some mud ark and rootlets occurring throughout. SUII comprised a similar light brown sandy matrix, although less shell and root material was noted.

\section{E8}

Three stratigraphic units were observed in Square E8 (Figure 10). SUI consisted of a dark coloured humic layer characterized by large amounts of rootlets and organic matter. SUII comprised poorly consolidated light brown sand. SUIII consisted of moist yellow sand and contained only small amounts of charcoal.

\section{E9}

The final test pit, E9, situated furthest from the creek along Transect $\mathrm{C}$, exhibited two stratigraphic units (Figure 11). SUI consisted of a moist, grey-brown soil matrix containing many rootlets and a small amount of charcoal $10-18 \mathrm{~cm}$ deep. SUII consisted of an unconsolidated brown-yellow soil matrix, containing only minute pieces of charcoal. The base of SUII was not reached before excavations were terminated.

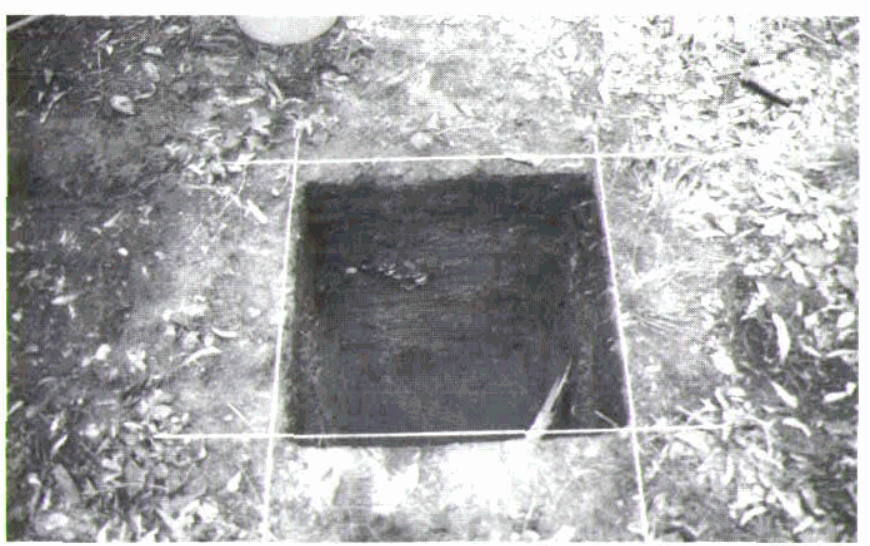

Figure 12. General view of completed excavation showing shell lens mid-way down the profile, Square E1, facing west (Photograph: S. Ulm).

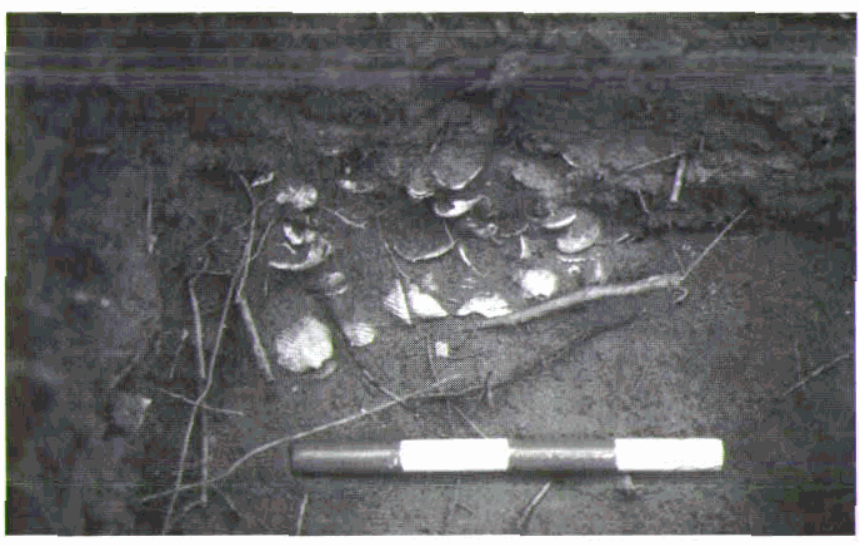

Figure 13. Close-up view of mud ark (Anadara trapezia) lens, Square E1, XU10, facing west (Photograph: S. Ulm).

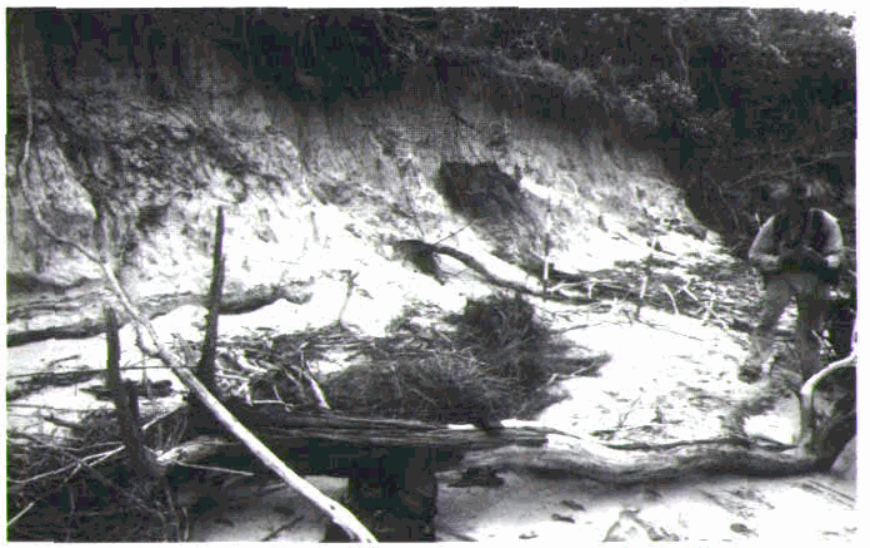

Figure 14. General view of massive bank erosion at the southern end of Eurimbula Site 1 fronting Round Hill Creek (Photograph: S. Ulm). 
Table 1. Radiocarbon dates for Eurimbula Site 1.

\begin{tabular}{|c|c|c|l|l|l|l|l|}
\hline Square & XU & $\begin{array}{c}\text { Depth } \\
(\mathbf{c m})\end{array}$ & Lab. No. & Sample & $\begin{array}{c}\text { Weight } \\
(\mathbf{g})\end{array}$ & ${ }^{14}$ C Age & \multicolumn{1}{|c|}{ Calibrated Age/s } \\
\hline E1 & 5 & 9.5 & Wk-5601 & charcoal & 2.5 & $220 \pm 80$ & $430\left(272,178,149,9,0^{*}\right) 0^{*}$ \\
\hline E1 & 10 & 35 & Wk-3944 & shell ${ }^{2}$ & 71.1 & $2390 \pm 60$ & $2170(1997) 1842$ \\
\hline E1 & 10 & 35 & Wk-5215 & charcoal & 2.1 & $1600 \pm 160$ & $1821(1412) 1167$ \\
\hline E2 & 9 & 50 & Wk-3945 & charcoal & 10.3 & $3020 \pm 70$ & $3352(3200,3197,3154) 2943$ \\
\hline Near E7 & surface & 0 & Wk-3946 & shell $^{\mathrm{a}}$ & 90.7 & $560 \pm 50$ & $300(234) 0 *$ \\
\hline
\end{tabular}

a Anadara trapezia

0* Represents a 'negative' or 'modern' age BP.

\section{Chronology}

Five radiocarbon determinations have been obtained from the excavations at Eurimbula Site 1 (Table 1; see Ulm and Lilley this volume:Appendix C for full details). Samples Wk-3944 and Wk-3946 are based on the estuarine bivalve Anadara trapezia. Conventional ${ }^{14} \mathrm{C}$ ages are corrected for ${ }^{13} \mathrm{C} /{ }^{12} \mathrm{C}$ fractionation and were calibrated using the CALIB (v3.0.3c) computer program (Stuiver and Reimer 1993). Determinations based on charcoal samples were calibrated using the bi-decal atmospheric calibration curve based on the datasets of Pearson and Stuiver (1993) and Stuiver and Pearson (1993) with no laboratory error multiplier. Forty years were subtracted before calibration to correct for ${ }^{14} \mathrm{C}$ variations between northern and southern hemispheres. Dates on marine shell samples were calibrated using the marine calibration dataset of Stuiver and Braziunas (1993) with a $\Delta \mathrm{R}$ correction value of $-5 \pm 35$. The calibrated ages reported span the $2 \sigma$ calibrated age-range.

Dates on a shell/charcoal sample pair (Wk-3944 and Wk-5215) from Square E1 were obtained in an attempt to determine the local marine reservoir effect in the Round Hill Creek estuary. The object was to assess the potential influence of localised variations in marine reservoir effect in determining the accurate radiocarbon age of marine shell specimens in archaeological deposits in the area. Studies of marine reservoir effect in enclosed embayments and estuaries elsewhere have demonstrated considerable variability in ${ }^{14} \mathrm{C}$ activity through space and time, suggesting significant variation in terrestrial carbon input and exchange with the open ocean (e.g. Kennett $e t$ al. 1997; Little 1993). Local reservoir effects are potentially a major factor in dating shell material from the Round Hill Creek estuary, as terrestriallyderived carbon mobilized in freshwater run-off from the extensive wetlands bordering the southwestern margins of the creek (see Olsen 1980:17) may have significantly altered ${ }^{14} \mathrm{C}$ activity within the estuarine environments.

The dates obtained on the paired samples from Square E1 exhibit an apparent difference of $790{ }^{14} \mathrm{C}$ years (Table 1). The expected maximum difference was $450 \pm 35$ years identified by Gillespie and Polach (1979) for open ocean waters along the east Australian coast reduced by the input of atmospheric ${ }^{14} \mathrm{C}$ into the estuary and hence shell structures, theoretically resulting in a date closer to the value obtained on the terrestrial charcoal. The most probable explanation for this wide discrepancy is a lack of a close temporal association between the shell and charcoal samples selected for radiocarbon determination. Although the apparently discrete shell lens from which the samples derive appeared to be a secure stratigraphic context, it is possible that bulk sampling of the lens from the section resulted in contamination by more recent charcoal fragments. Alternatively, this apparent anomaly may be accounted for by percolation of small charcoal fragments down the profile to become subsequently incorporated in the shell lens. It is unlikely that densely-packed shell valves with large surface areas such as that contained in the lens have moved far in the deposit (see Hughes and Lampert 1977).

Despite this problem, Eurimbula Site 1 has been shown to date from the end of the pre-European period to at least 3,200 years ago (Lilley et. al 1996). The top units of Square El date to the last 200-300 years, which accords with the recent date for surface shell collected near Square E7. Owing to the location of the excavations towards the seaward and thus more recently-formed edge of a prograding shoreline, these findings suggest survey and excavation of older beach ridge deposits to landward may locate material dating to at least the time of sea-level stabilization $6,000-7,000$ years ago. 


\section{Laboratory Procedures}

Prior to analysis of the excavated material, the $6 \mathrm{~mm}$ and $3 \mathrm{~mm}$ sieve residues were combined and wetsieved in freshwater. There are two main reasons for this procedure. First, apart from Square E1, there was very little residue retained for each excavation in either the fine or coarse sieves, obviating the need for selective laboratory sampling. In some cases, $3 \mathrm{~mm}$ sieve residues were not retained in the field if they consisted solely of modern organic material (i.e. roots). Second, some of the excavated material was still damp from wet-sieving in the field.

The excavated assemblage from Square E1 was analysed as part of an undergraduate independent study (Reid 1997). Owing to the large quantity of material recovered from this pit, Reid (1997) sorted and analysed the fine and coarse sieve residues separately. For the purpose of this report, however, the fine and coarse sieve residue data reported in Reid (1997) were combined for each excavation unit to facilitate analytical comparability.

Excavated material was sorted into the following categories: organic material (i.e. roots, leaf litter, seeds etc), shell species, fish bone, charcoal, scats, insect remains, non-artefactual stone, artefactual stone and ochre. Raw data for the main cultural materials recovered are presented in Appendix A-I.

Weight was selected to characterize the relative abundance of cultural remains across the site complex. The nature of the excavated shell assemblages was the major rationale for the selection of this method of quantification. Apart from E1, all the excavations contained relatively small amounts of highly fragmented shell material. Owing to the fragmented nature of the mollusc remains and the low representation of diagnostic features, such as hinges or umbos, weight was viewed as the most informative and efficient method of analysis.

\section{CULTURAL REMAINS}

\section{Vertebrate Fauna}

Very small numbers of fish bone were recovered, comprising the only vertebrate remains identified. The largest quantity of bone was evidenced in E1, which contained $0.9 \mathrm{~g}$ of burnt fish bone (Figure 15). Square E2 contained only $0.3 \mathrm{~g}$, E3 contained $0.1 \mathrm{~g}$ and $\mathrm{E} 4$ contained $0.6 \mathrm{~g}$ (Figures 16-18). No bone was identified in Squares E5-E9.

\section{Shell}

As surface observations indicated, the two dominant mollusc species excavated at Eurimbula Site 1 were commercial oyster (Saccostrea commercialis) and mud ark (Anadara trapezia). The largest proportion of shell material was recovered from $\mathrm{E} 1$, which contained just over $2 \mathrm{~kg}$ of oyster and mud ark combined (Figure 15). These two shell species exhibit a distinctly bi-modal vertical (temporal) distribution. The earlier deposits show a dominance of mud ark, whilst the later units illustrate a shift to exploitation of oyster. This bi-modal trend in the distribution of mollusc species is also apparent in E2 and E3, and may be the result of changed mollusc habitat conditions. Mud ark are found just below the surface of muddy substrates in estuaries, while oyster generally prefer clear water and a rocky substrate or mangrove roots. Reid (1997:17) hypothesised that there may have been a recent change in habitat conditions more favourable to oyster, replacing the earlier populations of mud ark (Shanco and Timmins 1975). However, the mud ark valves dated from near E7 suggest a recent age. Small quantities of mud ark are also represented in the upper undated deposits of E3, E4 and E7. E2 contained a total of $182.9 \mathrm{~g}$ of oyster and mud ark (Figure 16), whilst E3 contained a total of $217.6 \mathrm{~g}$ (Figure 17).

E7 contained a combined total of $217.6 \mathrm{~g}$ of mud ark and oyster (Figure 21). The remaining squares (E4, E5, E6, E8, E9) contained a combined total of less than 50g for these species (Figures 18-20, 22-23). Generally, the bulk of shell excavated appears in the pits excavated along Transect $A$ and in those closest to the bank of the creek in the other transects.

\section{Stone Artefacts}

In total 61 stone artefacts were recovered from the nine squares excavated at Eurimbula Site 1. Stone artefacts were recovered from only four of the nine test pits (E1, E2, E3 and E4), and represent a range of artefact types including flakes, flaked pieces and broken flakes as well as a single backed artefact (Table 2). Figures 15-18 illustrate the proportion of artefactual stone in comparison to the total assemblage. Five raw materials are represented in the assemblage: quartz (both white and clear), quartzite, pyroclastic rhyolite, silcrete and a coarse sandstone. While quartz and pyroclastic rhyolite occur locally, the remaining raw materials are non-local suggesting the movement of stone into the area. These materials had to be transported to the site from elsewhere, possibly from the coastal ranges to the west. Overall, pyroclastic rhyolite was the dominant raw material comprising $47.5 \%(n=29)$, although quart $z$ was also well represented with $34.5 \%(n=21)$. The fact that both raw materials are found locally does not make their dominance surprising.

Square E1 contained 35 stone artefacts, distributed throughout the excavated deposit with the majority consisting of flaked pieces. Pyroclastic rhyolite was the dominant raw material (77\%). Other raw materials present include quartz, sandstone and silcrete. A variety of stone artefact types are represented in this 
square including flaked pieces, two flakes and a single broken flake. A flake made on pyroclastic rhyolite was found towards the upper units of the excavation, while the flake made from silcrete was found towards the basal units of the excavation (see discussion below). Neither flake was large with maximum dimensions not exceeding $5 \mathrm{~mm}$. The broken flake made from pyroclastic rhyolite was transversely snapped and recovered from middle excavation units. Maximum dimensions of the stone artefacts range between $3 \mathrm{~mm}$ and $39 \mathrm{~mm}$ with an average maximum dimension of $9.5 \mathrm{~mm}$.

Square E2 contained 10 stone artefacts and displays a similar dominance of flaked pieces to Square E1. Despite this initial similarity, there is a greater variety of raw materials represented at Square E2 and the distribution of raw materials is more even. Quartz is the dominant raw material (40\%), followed by silcrete, sandstone, pyroclastic rhyolite and quartzite. With the exception of a single backed artefact, all artefacts are flaked pieces. The backed artefact was found in the second bottom excavation unit and is made from a creamy-yellow silcrete with maximum dimensions of $25 \mathrm{~mm} \times 9.5 \mathrm{~mm} \times 4 \mathrm{~mm}$. Every edge of this artefact has been modified, with 15 flake scars present on the 'back' of the artefact. The average maximum dimensions for artefacts from Square E2 is $16 \mathrm{~mm}$.

Square E3 contained 13 stone artefacts consisting entirely of flaked pieces. Quartz, both white and clear, is the dominant raw material $(92 \%)$ with only one artefact made from silcrete. The majority of artefacts found from Square E3 are from the basal excavation units, with just three artefacts recovered from the upper excavation units. The silcrete flaked piece was found in the second bottom excavation unit. The vertical provenience of this artefact is similar to other non-local raw materials found at the site. The maximum dimensions of artefacts range from $3 \mathrm{~mm}$ to $26 \mathrm{~mm}$.

Square E4 contained three stone flaked pieces. Two artefacts are manufactured from an extremely coarse and weathered sandstone with a dark reddishbrown cortex and a creamy to white pock-marked interior surface. One artefact from this square is made from pyroclastic rhyolite. All artefacts were found in the upper to middle units of the excavation. The maximum dimensions of these artefacts range from $5 \mathrm{~mm}$ to $39 \mathrm{~mm}$.

Clearly the dominant raw material type found at Eurimbula Site 1 was pyroclastic rhyolite, comprising $47.5 \%$ of the entire assemblage. Pyroclastic rhyolite dominates the headlands of the study area, such as Round Hill Head, and provided the closest source of this material. Quartz has been found throughout these headlands also. Quartz constitutes the second most abundant raw material used at the site at $34.5 \%$ of the assemblage. Artefacts made on non-local stone make up $18 \%$ of the lithic assemblage. Flaked artefacts dominate the assemblage in artefact types with $95 \%$ of the entire assemblage, while formal tool types were not commonly found.

Stone artefacts are concentrated at the southern end of the site in the vicinity of Transect A. In fact, E1 contains over half of the lithic assemblage recovered from the entire site. Significantly, there was a general pattern for non-local raw material to be located towards the basal units of excavation. This pattern was noted in Squares E1, E2 and E3. Owing to the general location of these raw material types in the excavations and based on the limited dating of the site, it seems likely these artefacts are generally older than artefacts produced on local stone sources. This may indicate a change in raw material focus in the local area and identifies an important change in resource use that requires further investigation.

Table 2. Stone artefacts from Eurimbula Site 1.

\begin{tabular}{|c|l|c|c|c|c|c|c|}
\hline \multirow{2}{*}{ Square } & \multirow{2}{*}{ Artefact Type } & \multirow{2}{*}{$\#$} & \multicolumn{6}{|c|}{ Raw Material } \\
\cline { 4 - 8 } & & & Rhyolite & Quartz & Sandstone & Silcrete & Quartzite \\
\hline E1 & Flaked Piece & 32 & 25 & 5 & 2 & - & - \\
\hline E1 & Flake & 2 & 1 & - & - & 1 & - \\
\hline E1 & Broken Flake & 1 & 1 & - & - & - & - \\
\hline E2 & Flaked Piece & 9 & 1 & 4 & 1 & 2 & 1 \\
\hline E2 & Backed Artefact & 1 & - & - & - & 1 & - \\
\hline E3 & Flaked Piece & 13 & - & 12 & - & 1 & - \\
\hline E4 & Flaked Piece & 3 & 1 & - & 2 & - & \\
\hline TOTAL & & 61 & 29 & 21 & 5 & 5 & 1 \\
\hline
\end{tabular}




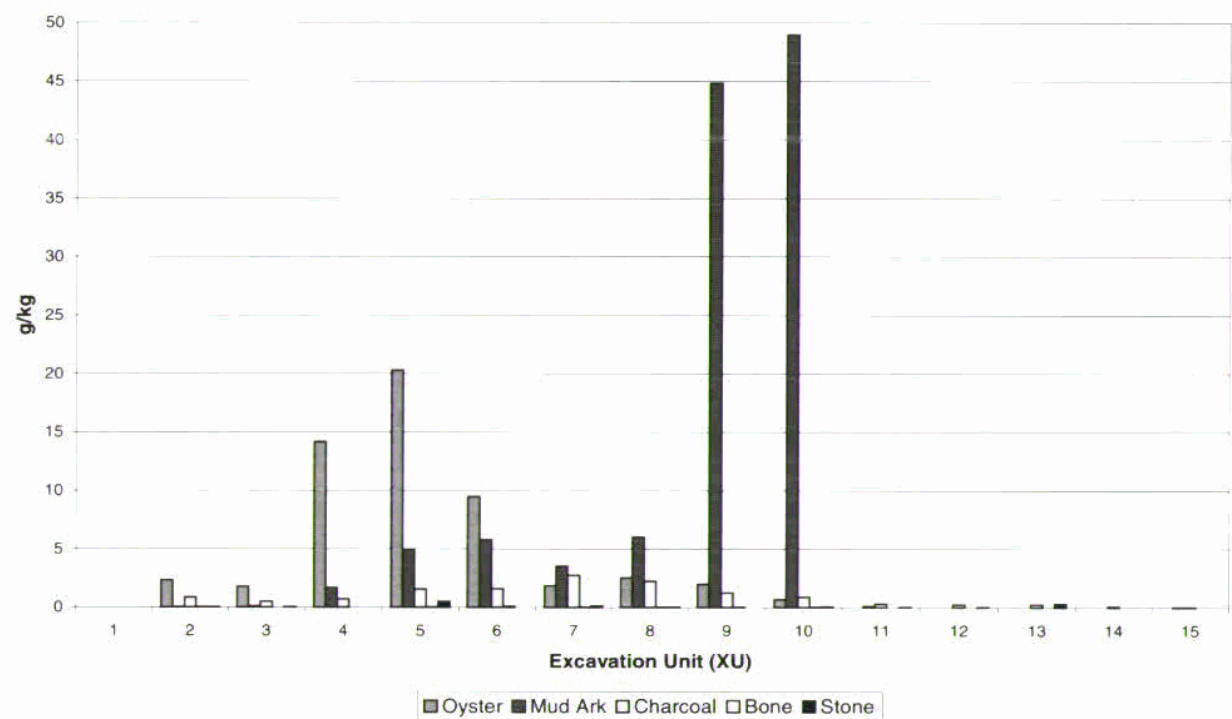

Figure 15. Cultural remains in Square E1.

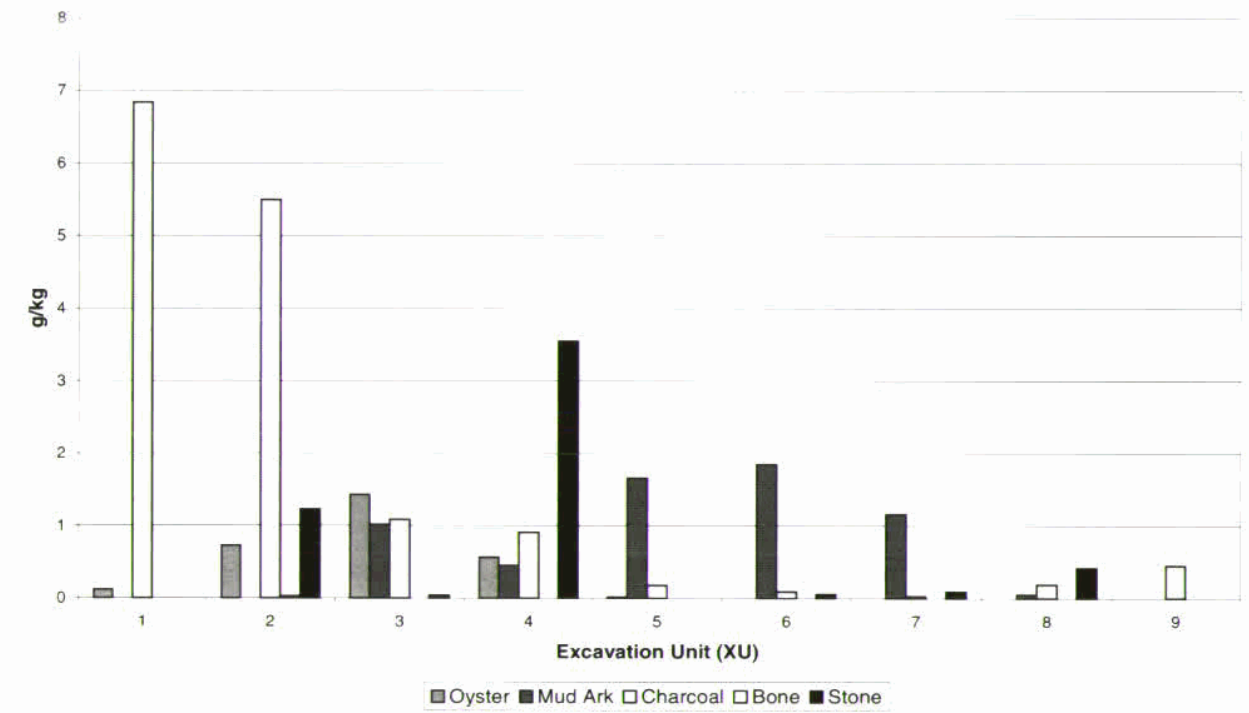

Figure 16. Cultural remains in Square E2.

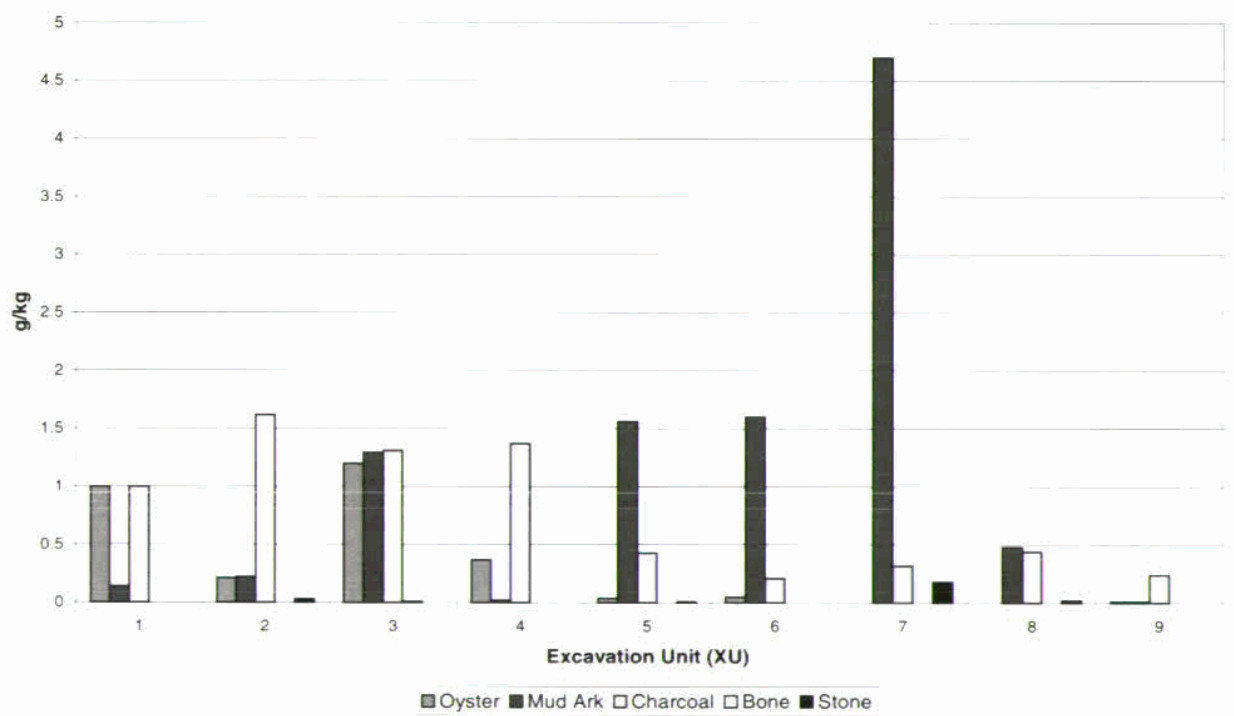

Figure 17. Cultural remains in Square E3. 


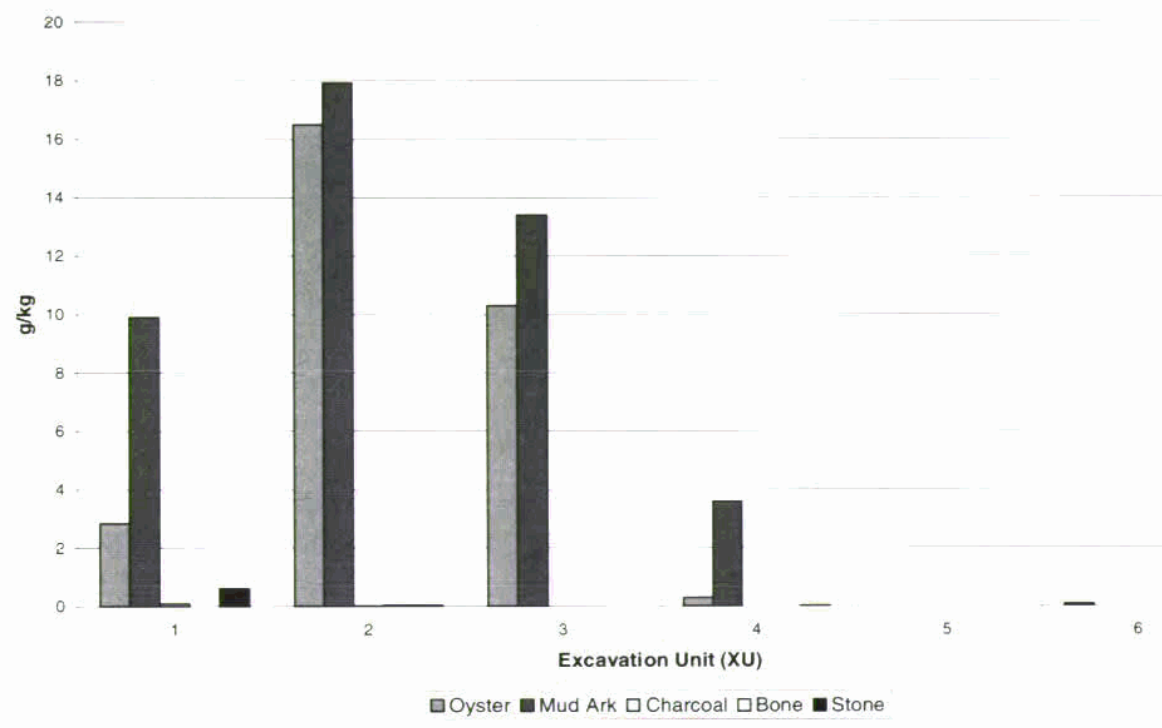

Figure 18. Cultural remains in Square E4.

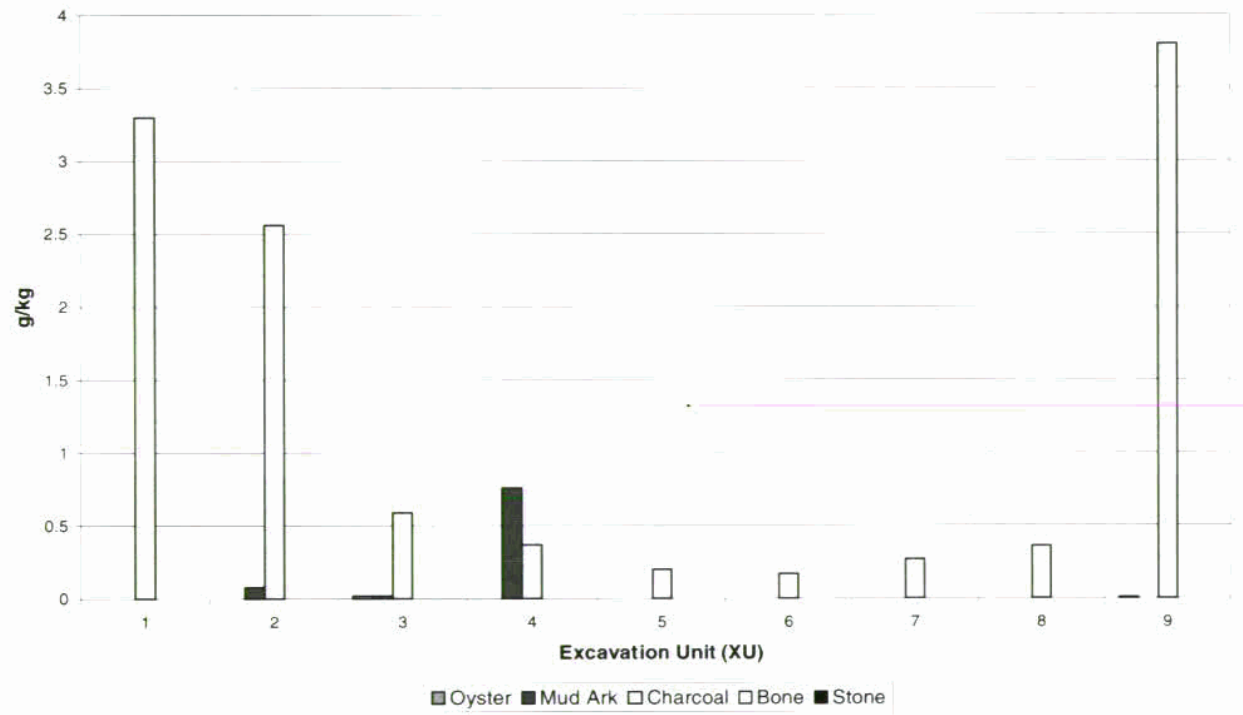

Figure 19. Cultural remains in Square E5.

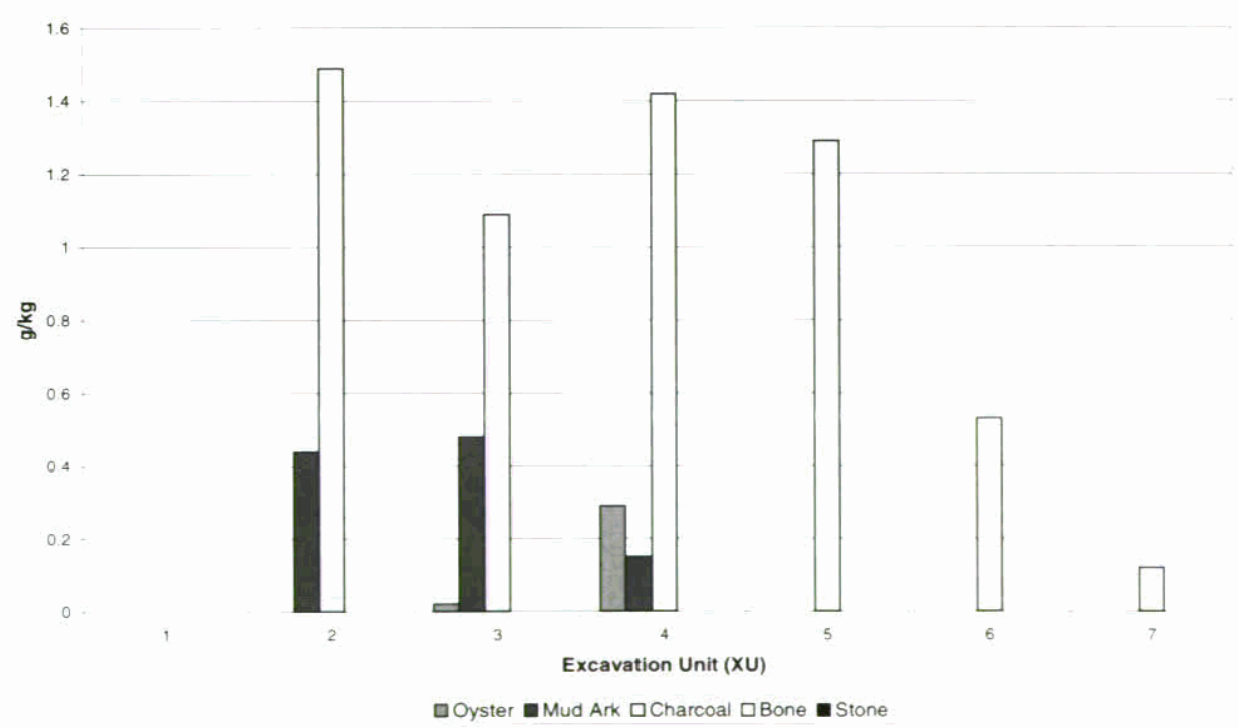

Figure 20. Cultural remains in Square E6. 


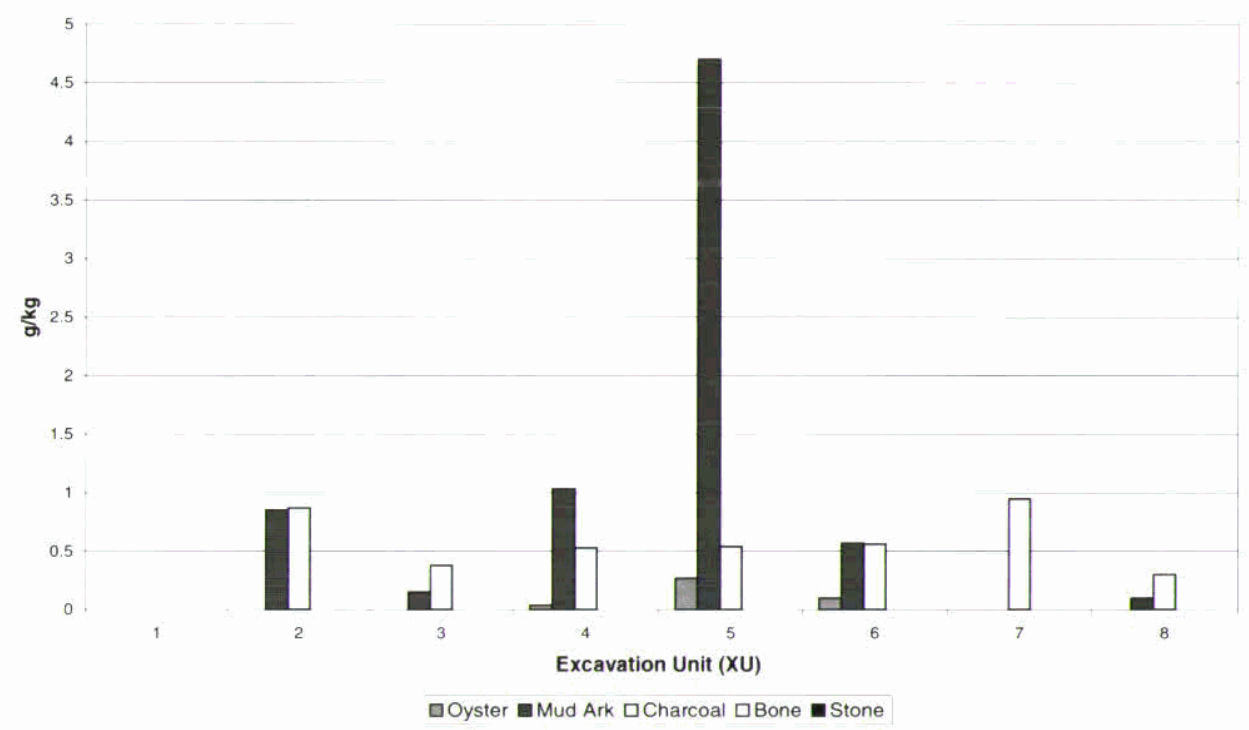

Figure 21. Cultural remains in Square E7.

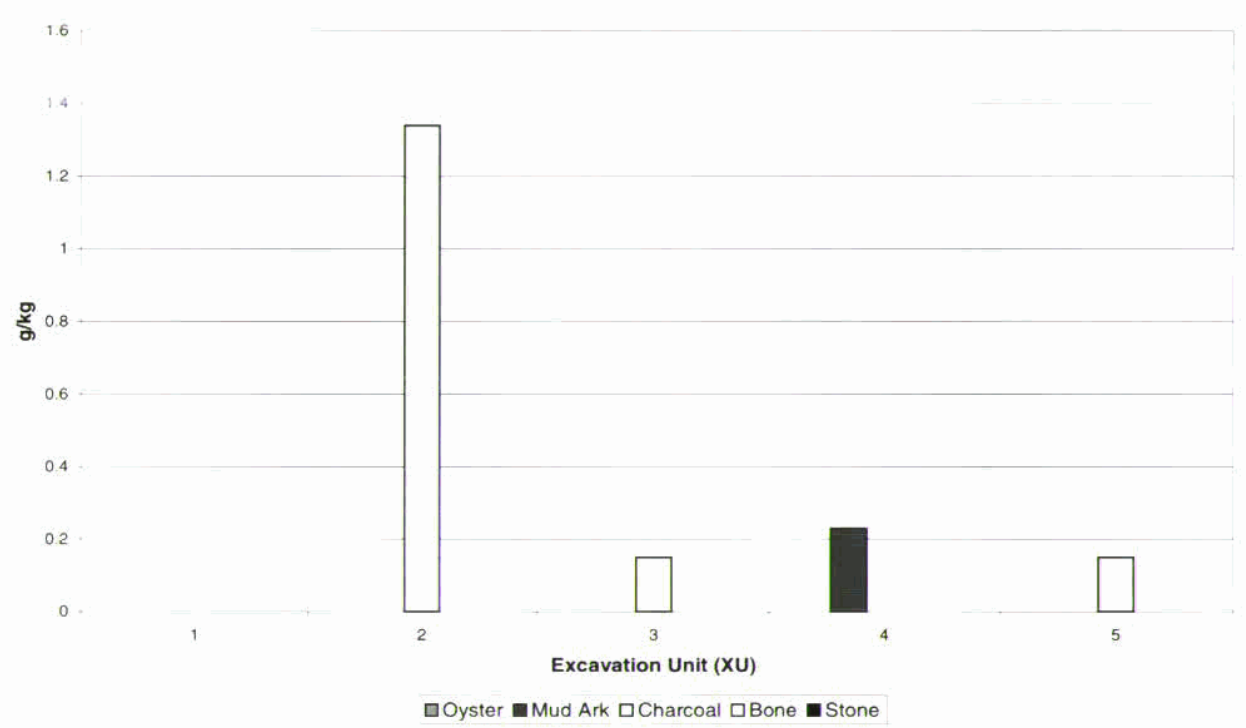

Figure 22. Cultural remains in Square E8.

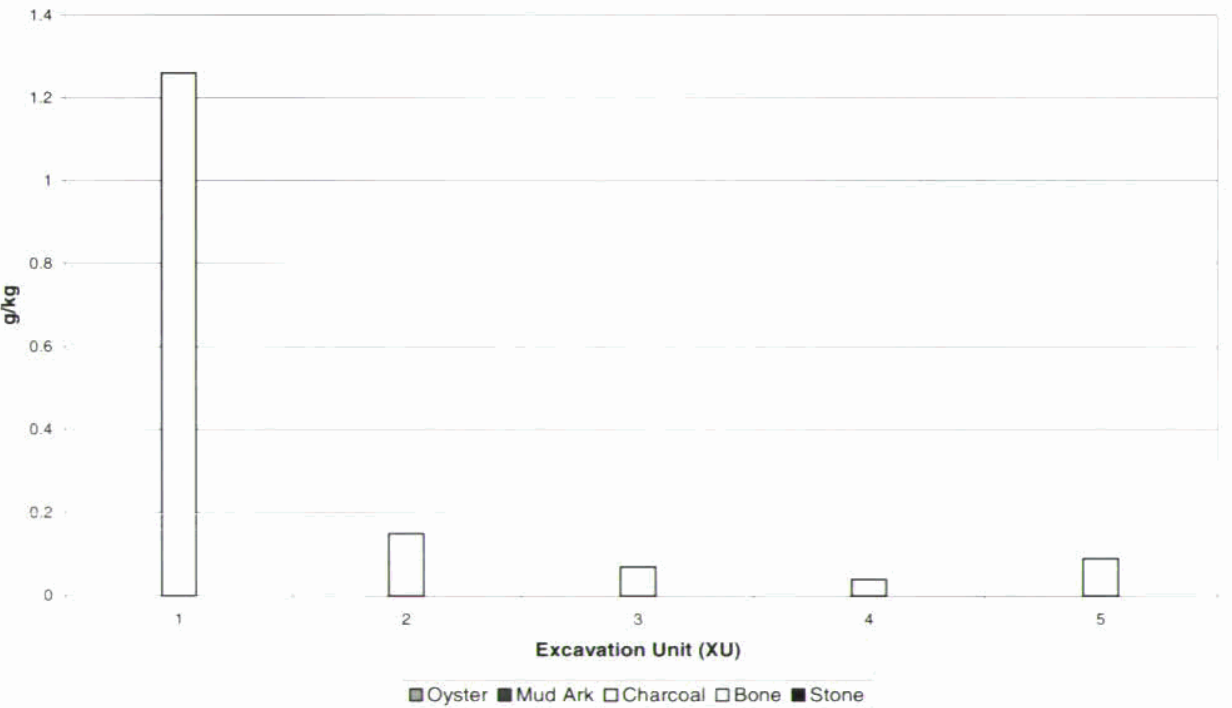

Figure 23. Cultural remains in Square E9. 


\section{Charcoal}

The largest quantity of charcoal recovered was from E5, weighing a total of $197.9 \mathrm{~g}$ (Figure 19). The bulk of this deposit, however, was from XU9, where the excavation of a burnt root was recorded, suggesting that the apparent charcoal peak is largely natural in origin. E1 contained the second largest quantity of charcoal, with a total of $190.4 \mathrm{~g}$ (Figure 15). The general trend in charcoal recovered from the excavations revealed a decrease in quantity as distance from the creek increases.

\section{Discussion}

As Figures 15-17 indicate, the largest concentration of cultural material recovered by the excavations occurs in Squares E1, E2 and E3 along Transect A. Although small quantities of cultural material occur in the remaining pits, there appears to be a general decrease in quantity and diversity seaward. E4 and E7 (Figures 18, 21), however, do contain substantial quantities of cultural remains in comparison to the other pits of Transect B and C. This evidence suggests that occupation was concentrated along the creek margin, immediately adjacent to the diverse resources it offered. The presence of bevelled-edged implements morphologically similar to those functionally associated with plant food processing in southeast Queensland suggests that a range of subsistence activities took place at the site. The concentration of cultural remains along Transect A may also reflect a conscious subsistence strategy. This transect is situated close to a variety of environmental zones, including open forest habitats, extensive estuarine mangrove communities and tidal flats at the southern end of Round Hill Creek and freshwater swamps to the southwest (Olsen 1980; QDEH 1994). The diversity of resources offered by these environments may have been a factor in the more intensive occupation in the area of this transect. Conversely, evidence for the decrease in cultural material seaward from this transect may simply be related to variability in local resource availability, with a reduction in the area of intertidal flats towards the ocean.

\section{Conclusion}

The results of analysis suggest that at Eurimbula Site 1 there is no obvious connection between the deposition of cultural remains and the formation of beach ridges. The quantity and location of cultural remains recovered in the excavations, however, strongly suggest that resource availability was a major factor in structuring local settlement patterns and hence deposition of cultural material. Regardless of whether the beach ridges at Eurimbula were continuous formations or the products of episodic progradation, evidence suggests that the geomorphological occurrences of the last 3,000 years did not affect subsistence patterns which were strongly focussed on Round Hill Creek rather than the ocean beach.

\section{Acknowledgments}

We thank our field assistants for all their hard work on the excavation: Deborah Brian, Chris Clarkson, Leo Miller, Catriona Murray, John Richter, Deb Vale. Hilton (Charlie) Johnson and Ron Johnson (Jr) of the Gurang Land Council Aboriginal Corporation also assisted throughout the excavations. Other Gooreng people visited the site during the excavations and we thank Michael Williams, James Williams and Cedric Williams for their support. We also thank John Richter for drawing the figures. Thanks to Des Mergard and family of 1770 Charter for transporting us to the site in their LARC. Funding for fieldwork was provided by the National Estate Grants Program and the Aboriginal and Torres Strait Islander Studies Unit at the University of Queensland.

\section{References}

Burke, C. 1993 A Survey of Aboriginal Archaeological Sites on the Curtis Coast, Central Queensland. Unpublished report to the Queensland Department of Environment and Heritage, Rockhampton.

Carter, M. 1997 Chenier and Shell Midden: An Investigation of Cultural and Natural Shell Deposits at Rodds Peninsula, Central Queensland Coast. Unpublished B.A. (Hons) thesis, Department of Anthropology and Sociology, University of Queensland, Brisbane.

Carter, M., I. Lilley, S. Ulm and D. Brian this volume Mort Creek Site Complex, Curtis Coast: Site report. Queensland Archaeological Research 11.

Gillespie, R. and H.A. Polach 1979 The suitability of marine shells for radiocarbon dating of Australian prehistory. In R. Berger and H.E. Suess (eds), Radiocarbon Dating: Proceedings of the Ninth International Conference, Los Angeles and La Jolla 1976, pp.404-421. Berkeley: University of California Press.

Gillieson, D.S. and J. Hall 1982 Bevelling bungwall bashers: A use-wear study from southeast Queensland. Australian Archaeology 14:43-61.

Godwin, L. 1990 Cultural heritage. In J. McCosker, Eurimbula National Park Draft Management Plan. Unpublished report to the Queensland Department of Environment and Heritage, Rockhampton.

Hopley, D. 1985 The Queensland coastline: Attributes and issues. In J.H. Holmes (ed.), Queensland: A Geographical Interpretation, pp.73-94. Brisbane: Booralong Publications. 
Hughes, P.J. and R.J. Lampert 1977 Occupational disturbance and types of archaeological deposit. Journal of Archaeological Science 4:35-40.

Kennett, D.J., B.L. Ingram, J.M. Erlandson and P.L. Walker 1997 Evidence for temporal fluctuations in marine radiocarbon reservoir ages in the Santa Barbara Channel, southern California. Journal of Archaeological Science 24:1051-1059.

Lilley, I. and S. Ulm 1995 The Gooreng Gooreng Cultural Heritage Project: Some proposed directions and preliminary results of the archaeological program. Australian Archaeology 41:11-15.

Lilley, I. and S. Ulm this volume The Gooreng Gooreng Cultural Heritage Project: Preliminary results of archaeological research, 1993-1997. Queensland Archaeological Research 11.

Lilley, I., S. Ulm and D. Brian 1996 The Gooreng Gooreng Cultural Heritage Project: First radiocarbon determinations. Australian Archaeology 43:38-40.

Little, E.A. 1993 Radiocarbon age calibration at archaeological sites of coastal Massachusetts and vicinity. Journal of Archaeological Science 20:457471.

McNiven, I. 1992 Bevel-edged tools from coastal southeast Queensland. Antiquity 66:701-709.

Pearson, G.W. and M. Stuiver 1993 High-precision bidecadal calibration of the radiocarbon time scale, 500-2500 BC. Radiocarbon 35:25-33.

QDEH 1994 Curtis Coast Study: Resource Report. Rockhampton: Department of Environment and Heritage.

Olsen, H.F. 1980 Estuarine resource inventory and evaluation for the coastal strip between Round Hill Head and Tannum Sands, Queensland. In H.F. Olsen, R.M. Dowling and D. Bateman 1980 Biological Resources Investigation (Estuarine Inventory), pp. 1-44. Queensland Fisheries Service Research Bulletin 2. Brisbane: Queensland Fisheries Service.

Reid, J. 1997 Results and Analysis of E1: An Investigation of the Archaeological Record of the Eurimbula Shell Midden Complex, Central Queensland Coast. Unpublished report submitted for ID232: Independent Project in Aboriginal and Torres Strait Islander Studies I, Aboriginal and Torres Strait Islander Studies Unit, University of Queensland, Brisbane.

Reid, J. 1998 An Archaeological Approach to Quarry Studies: A Technological Analysis of the Ironbark Site Complex, Southern Curtis Coast, Australia. Unpublished B.A. (Hons) thesis, Department of Anthropology and Sociology, University of Queensland, Brisbane.

Richter, J. 1994 A Pound of Bungwall and Other Measures. Unpublished B.A. (Hons) thesis, Department of Anthropology and Sociology, University of Queensland, Brisbane.

Rowland, M. 1987 Preliminary Archaeological Survey of Coastal Areas of the Bundaberg 1:250,000 sheet (KE). Unpublished report to the Queensland Department of Environment and Heritage, Brisbane.

Shanco, P and R. Timmins 1975 Reconnaissance of southern Bustard Bay tidal wetlands. Operculum October:149-154.

Stuiver, M and T.F. Braziunas 1993 Modeling atmospheric ${ }^{14} \mathrm{C}$ influences and ${ }^{14} \mathrm{C}$ ages of marine samples to 10,000 BC. Radiocarbon 35(1):137-189.

Stuiver, M. and G.W. Pearson 1993 High-precision bidecadal calibration of the radiocarbon time scale, AD 1950-500 BC and 2500-6000 BC. Radiocarbon 35:123.

Stuiver, $\mathrm{M}$ and P.J. Reimer 1993 Extended ${ }^{14} \mathrm{C}$ data base and revised CALIB $3.0{ }^{14} \mathrm{C}$ age calibration program. Radiocarbon 35(1):215-230.

Tanner, W. 1995 Origins of beach ridges and swales. Marine Geology 129:149-161.

Ulm, S. and I. Lilley this volume The archaeology of the southern Curtis Coast: An overview. Queensland Archaeological Research 11. 
Appendix A. Eurimbula Site 1, Square E1, Excavation Data and Dominant Materials.

\begin{tabular}{|c|c|c|c|c|c|c|c|c|}
\hline $\mathbf{X U}$ & $\begin{array}{c}\text { Mean XU } \\
\text { Depth }(\mathrm{cm})\end{array}$ & $\begin{array}{c}\text { XU Weight } \\
\text { (kg) }\end{array}$ & $\begin{array}{l}\text { Oyster }^{2} \\
\text { (g) }\end{array}$ & $\begin{array}{l}\text { Mud Ark } \\
\text { (g) }\end{array}$ & $\begin{array}{c}\text { Charcoal } \\
\text { (g) }\end{array}$ & $\begin{array}{c}\text { Bone } \\
\text { (g) }\end{array}$ & $\begin{array}{c}\text { Artefactual } \\
\text { Stone (g) }\end{array}$ & $\begin{array}{c}\text { Organic } \\
\text { Material (g) }\end{array}$ \\
\hline 1 & 0.5 & NA & NA & NA & NA & NA & NA & NA \\
\hline 2 & 3.8 & 11.5 & 26.8 & 0.1 & 10.0 & $<0.1$ & 0.5 & 71.0 \\
\hline 3 & 6.6 & 11.5 & 20.6 & 1.3 & 5.7 & 0 & 0.3 & 84.9 \\
\hline 4 & 7.7 & 11.5 & 163.0 & 19.5 & 8.4 & 0 & 0 & 66.5 \\
\hline 5 & 11.3 & 13.0 & 263.9 & 64.3 & 17.9 & $<0.1$ & 6.6 & 100.7 \\
\hline 6 & 15.2 & 15.0 & 142.7 & 87.0 & 24.0 & 1.5 & 0 & 67.2 \\
\hline 7 & 21.2 & 16.0 & 29.9 & 57.0 & 43.9 & 0.3 & 2.1 & 29.8 \\
\hline 8 & 28.0 & 16.5 & 41.6 & 99.2 & 37.4 & 0.5 & 0.3 & 32.9 \\
\hline 9 & 33.9 & 17.0 & 34.4 & 761.9 & 21.1 & 0.3 & 0 & 33.1 \\
\hline 10 & 37.7 & 12.8 & 8.8 & 627.0 & 11.2 & 0.2 & 1.0 & 20.9 \\
\hline 11 & 42.9 & 15.5 & 0 & 1.9 & 5.1 & 0 & 0.1 & 13.3 \\
\hline 12 & 47.7 & 16.8 & 0 & 0 & 4.4 & 0 & 0.2 & 10.5 \\
\hline 13 & 53.4 & 15.5 & 0 & 0 & 3.6 & 0 & 5.0 & 18.2 \\
\hline 14 & 60.2 & 18.0 & 0 & 0 & 1.0 & 0 & 0 & 6.3 \\
\hline 15 & 66.6 & 18.5 & 0 & $<0.1$ & 0.3 & 0 & 0 & 7.6 \\
\hline
\end{tabular}

a Saccostrea commercialis

Anadara trapezia

Appendix B. Eurimbula Site 1, Square E2, Excavation Data and Dominant Materials.

\begin{tabular}{|c|c|c|c|c|c|c|c|c|}
\hline XU & $\begin{array}{c}\text { Mean XU } \\
\text { Depth (cm) }\end{array}$ & $\begin{array}{c}\text { XU Weight } \\
(\mathbf{k g})\end{array}$ & $\begin{array}{c}\text { Oyster } \\
(\mathbf{g})\end{array}$ & $\begin{array}{c}\text { Mud Ark } \\
(\mathbf{g})\end{array}$ & $\begin{array}{c}\text { Charcoal } \\
(\mathbf{g})\end{array}$ & $\begin{array}{c}\text { Bone } \\
(\mathbf{g})\end{array}$ & $\begin{array}{c}\text { Artefactual } \\
\text { Stone }(\mathrm{g})\end{array}$ & $\begin{array}{c}\text { Organic } \\
\text { Material }(\mathbf{g})\end{array}$ \\
\hline 1 & 2.4 & 2.5 & 0.3 & 0 & 17.1 & 0 & 0 & 0 \\
\hline 2 & 9.0 & 15.5 & 11.3 & 0 & 85.3 & 0.5 & 19.1 & 3.3 \\
\hline 3 & 13.2 & 19.0 & 27.1 & 19.3 & 20.7 & 0 & 0.8 & 2.8 \\
\hline 4 & 17.5 & 17.5 & 9.9 & 7.9 & 16.0 & 0 & 12.7 & 1.0 \\
\hline 5 & 25.4 & 19.0 & 0.4 & 31.6 & 3.5 & 0 & 0 & 0.5 \\
\hline 6 & 33.1 & 24.0 & 0 & 44.4 & 2.1 & 0 & 1.5 & 0 \\
\hline 7 & 39.0 & 21.0 & 0 & 24.4 & 0.6 & 0 & 1.8 & 0 \\
\hline 8 & 44.6 & 19.0 & 0 & 1.0 & 3.6 & 0 & 8.0 & 0 \\
\hline 9 & 51.1 & 23.5 & 0 & 0 & 10.6 & 0 & 0 & 6.8 \\
\hline
\end{tabular}

Saccostrea commercialis

Anadara trapezia 
Appendix C. Eurimbula Site 1, Square E3, Excavation Data and Dominant Materials.

\begin{tabular}{|c|c|c|c|c|c|c|c|c|}
\hline XU & $\begin{array}{c}\text { Mean XU } \\
\text { Depth }(\mathbf{c m})\end{array}$ & $\begin{array}{c}\text { XU Weight } \\
(\mathbf{k g})\end{array}$ & $\begin{array}{c}\text { Oyster } \\
(\mathbf{g})\end{array}$ & $\begin{array}{c}\text { Mud Ark } \\
(\mathbf{g})\end{array}$ & $\begin{array}{c}\text { Charcoal } \\
(\mathbf{g})\end{array}$ & $\begin{array}{c}\text { Bone } \\
(\mathbf{g})\end{array}$ & $\begin{array}{c}\text { Artefactual } \\
\text { Stone (g) }\end{array}$ & $\begin{array}{c}\text { Organic } \\
\text { Material (g) }\end{array}$ \\
\hline 1 & 0.6 & 0.7 & 0.7 & 0.1 & 0.7 & 0 & 0 & 33.0 \\
\hline 2 & 7.1 & 9.0 & 1.9 & 2 & 14.6 & 0 & 0.3 & 152.1 \\
\hline 3 & 12.3 & 17.5 & 21.0 & 22.5 & 23.0 & 0.1 & 0 & 63.5 \\
\hline 4 & 17.4 & 17.6 & 6.5 & 0.4 & 24.1 & 0 & 0 & 58.3 \\
\hline 5 & 22.9 & 17.8 & 0.8 & 27.8 & 7.7 & 0 & $<0.1$ & 48.2 \\
\hline 6 & 28.4 & 18.4 & 1.0 & 29.5 & 3.8 & 0 & 0 & 37.4 \\
\hline 7 & 34.1 & 18.7 & 0 & 87.9 & 6.0 & 0 & 3.3 & 19.7 \\
\hline 8 & 38.6 & 19.0 & 0 & 9.1 & 8.4 & 0 & 0.3 & 13.2 \\
\hline 9 & 47.7 & 24.8 & 0.2 & 0.2 & 5.9 & 0 & 0 & 9.6 \\
\hline
\end{tabular}

a Saccostrea commercialis

b Anadara trapezia

Appendix D. Eurimbula Site 1, Square E4, Excavation Data and Dominant Materials.

\begin{tabular}{|c|c|c|c|c|c|c|c|c|}
\hline XU & $\begin{array}{c}\text { Mean XU } \\
\text { Depth (cm) }\end{array}$ & $\begin{array}{c}\text { XU Weight } \\
(\mathbf{k g})\end{array}$ & $\begin{array}{c}\text { Oyster }^{\mathbf{2}} \\
(\mathbf{g})\end{array}$ & $\begin{array}{c}\text { Mud Ark } \\
(\mathbf{g})\end{array}$ & $\begin{array}{c}\text { Charcoal } \\
(\mathbf{g})\end{array}$ & $\begin{array}{c}\text { Bone } \\
(\mathbf{g})\end{array}$ & $\begin{array}{c}\text { Artefactual } \\
\text { Stone (g) }\end{array}$ & $\begin{array}{c}\text { Organic } \\
\text { Material (g) }\end{array}$ \\
\hline 1 & 4.2 & 14.5 & 41.0 & 143.6 & 1.2 & 0 & 8.8 & 8.9 \\
\hline 2 & 9.2 & 15.0 & 247.5 & 268.6 & $<0.1$ & 0.8 & 0.7 & 3 \\
\hline 3 & 15.0 & 18.0 & 185.5 & 241.4 & 0 & 0 & 0 & 1.5 \\
\hline 4 & 20.0 & 16.0 & 4.6 & 57.3 & 0 & 0 & 0.2 & 0.3 \\
\hline 5 & 23.9 & 17.0 & 0 & 0 & 0 & 0 & 0 & 0 \\
\hline 6 & 29.5 & 19.5 & 1.3 & 0 & 0 & 0 & 0 & 0 \\
\hline
\end{tabular}

a Saccostrea commercialis

b Anadara trapezia 
Appendix E. Eurimbula Site 1, Square E5, Excavation Data and Dominant Materials.

\begin{tabular}{|c|c|c|c|c|c|c|c|c|}
\hline XU & $\begin{array}{c}\text { Mean XU } \\
\text { Depth (cm) }\end{array}$ & $\begin{array}{c}\text { XU Weight } \\
(\mathbf{k g})\end{array}$ & $\begin{array}{c}\text { Oyster } \\
(\mathbf{g})\end{array}$ & $\begin{array}{c}\text { Mud Ark } \\
(\mathbf{g})\end{array}$ & $\begin{array}{c}\text { Charcoal } \\
(\mathbf{g})\end{array}$ & $\begin{array}{c}\text { Bone } \\
(\mathbf{g})\end{array}$ & $\begin{array}{c}\text { Artefactual } \\
\text { Stone (g) }\end{array}$ & $\begin{array}{c}\text { Organic } \\
\text { Material (g) }\end{array}$ \\
\hline 1 & 1.0 & 1.0 & 0 & 0 & 3.3 & 0 & 0 & 1.7 \\
\hline 2 & 5.4 & 15.8 & 0 & 1.3 & 40.5 & 0 & 0 & 85.9 \\
\hline 3 & 10.2 & 17.5 & 0.3 & 0.3 & 10.4 & 0 & 0 & 18.4 \\
\hline 4 & 13.6 & 18.7 & 0 & 14.2 & 6.9 & 0 & 0 & 12.8 \\
\hline 5 & 19.2 & 19.3 & 0 & 0 & 3.8 & 0 & 0 & 10.8 \\
\hline 6 & 24.9 & 21.3 & 0 & 0 & 3.6 & 0 & 0 & 9.1 \\
\hline 7 & 30.5 & 21.1 & 0 & 0 & 5.7 & 0 & 0 & 6.1 \\
\hline 8 & 35.8 & 20.3 & 0 & 0 & 7.3 & 0 & 0 & 4.0 \\
\hline 9 & 44.4 & 30.5 & 0.2 & 0 & 115.9 & 0 & 0 & 6.2 \\
\hline
\end{tabular}

a Saccostrea commercialis

b Anadara trapezia

\section{Appendix F. Eurimbula Site 1, Square E6, Excavation Data and Dominant Materials.}

\begin{tabular}{|c|c|c|c|c|c|c|c|c|}
\hline XU & $\begin{array}{c}\text { Mean XU } \\
\text { Depth }(\mathbf{c m})\end{array}$ & $\begin{array}{c}\text { XU Weight } \\
(\mathbf{k g})\end{array}$ & $\begin{array}{c}\text { Oyster } \\
(\mathbf{g})\end{array}$ & $\begin{array}{c}\text { Mud Ark } \\
(\mathbf{g})\end{array}$ & $\begin{array}{c}\text { Charcoal } \\
(\mathbf{g})\end{array}$ & $\begin{array}{c}\text { Bone } \\
(\mathbf{g})\end{array}$ & $\begin{array}{c}\text { Artefactual } \\
\text { Stone }(\mathrm{g})\end{array}$ & $\begin{array}{c}\text { Organic } \\
\text { Material (g) }\end{array}$ \\
\hline 1 & 3.8 & 1.0 & NA & NA & NA & NA & NA & NA \\
\hline 2 & 6.9 & 18.0 & 0 & 7.9 & 26.8 & 0 & 0 & 268.3 \\
\hline 3 & 13.2 & 18.0 & 0.4 & 8.6 & 19.7 & 0 & 0 & 90.0 \\
\hline 4 & 17.6 & 17.5 & 5.1 & 2.7 & 24.9 & 0 & 0 & 16.2 \\
\hline 5 & 24.2 & 19.5 & 0 & 0 & 25.1 & 0 & 0 & 32.0 \\
\hline 6 & 29.4 & 20.0 & 0 & 0 & 10.5 & 0 & 0 & 5.6 \\
\hline 7 & 43.1 & 50.0 & 0 & 0 & 5.8 & 0 & & 0 \\
\hline
\end{tabular}

a Saccostrea commercialis

b Anadara trapezia 
Appendix G. Eurimbula Site 1, Square E7, Excavation Data and Dominant Materials.

\begin{tabular}{|c|c|c|c|c|c|c|c|c|}
\hline XU & $\begin{array}{c}\text { Mean XU } \\
\text { Depth (cm) }\end{array}$ & $\begin{array}{c}\text { XU Weight } \\
(\mathbf{k g})\end{array}$ & $\begin{array}{c}\text { Oyster } \\
(\mathbf{g})\end{array}$ & $\begin{array}{c}\text { Mud Ark } \\
(\mathbf{g})\end{array}$ & $\begin{array}{c}\text { Charcoal } \\
(\mathbf{g})\end{array}$ & $\begin{array}{c}\text { Bone } \\
(\mathbf{g})\end{array}$ & $\begin{array}{c}\text { Artefactual } \\
\text { Stone (g) }\end{array}$ & $\begin{array}{c}\text { Organic } \\
\text { Material (g) }\end{array}$ \\
\hline 1 & 0.8 & 0.6 & 0 & 0 & 0 & 0 & 0 & 0 \\
\hline 2 & 5.8 & 17.1 & 0 & 14.6 & 14.8 & 0 & 0 & 120.9 \\
\hline 3 & 11.6 & 17.3 & 0 & 2.6 & 6.5 & 0 & 0 & 46.6 \\
\hline 4 & 18.8 & 20.1 & 0.8 & 20.8 & 10.6 & 0 & 0 & 56.3 \\
\hline 5 & 24.0 & 17.6 & 4.7 & 82.8 & 9.5 & 0 & 0 & 27.9 \\
\hline 6 & 29.9 & 21.0 & 2.1 & 12.0 & 11.8 & 0 & 0 & 20.3 \\
\hline 7 & 35.9 & 20.0 & 0 & 0 & 18.9 & 0 & 0 & 18.8 \\
\hline 8 & 45.8 & 37.0 & 0 & 3.7 & 11.1 & 0 & 0 & 29.6 \\
\hline
\end{tabular}

a Saccostrea commercialis

b Anadara trapezia

Appendix H. Eurimbula Site 1, Square E8, Excavation Data and Dominant Materials.

\begin{tabular}{|c|c|c|c|c|c|c|c|c|}
\hline XU & $\begin{array}{c}\text { Mean XU } \\
\text { Depth (cm) }\end{array}$ & $\begin{array}{c}\text { XU Weight } \\
(\mathbf{k g})\end{array}$ & $\begin{array}{c}\text { Oyster } \\
(\mathbf{g})\end{array}$ & $\begin{array}{c}\text { Mud Ark } \\
(\mathbf{g})\end{array}$ & $\begin{array}{c}\text { Charcoal } \\
(\mathbf{g})\end{array}$ & $\begin{array}{c}\text { Bone } \\
(\mathbf{g})\end{array}$ & $\begin{array}{c}\text { Artefactual } \\
\text { Stone (g) }\end{array}$ & $\begin{array}{c}\text { Organic } \\
\text { Material } \\
(\mathbf{g})\end{array}$ \\
\hline 1 & 1.0 & 0.5 & NA & NA & NA & NA & NA & NA \\
\hline 2 & 6.2 & 17.8 & 0 & 0 & 23.9 & 0 & 0 & 34.6 \\
\hline 3 & 11.6 & 17.5 & 0 & 0 & 2.7 & 0 & 0 & 64.7 \\
\hline 4 & 23.4 & 27.5 & 0 & 6.3 & 0 & 0 & 0 & 0 \\
\hline 5 & 33.4 & 27.0 & 0 & 0 & 4.0 & 0 & 0 & 0.2 \\
\hline
\end{tabular}

a Saccostrea commercialis

b Anadara trapezia

Appendix I. Eurimbula Site 1, Square E9, Excavation Data and Dominant Materials.

\begin{tabular}{|c|c|c|c|c|c|c|c|c|}
\hline XU & $\begin{array}{c}\text { Mean XU } \\
\text { Depth (cm) }\end{array}$ & $\begin{array}{c}\text { XU Weight } \\
(\mathbf{k g})\end{array}$ & $\begin{array}{c}\text { Oyster } \\
(\mathbf{g})\end{array}$ & $\begin{array}{c}\text { Mud Ark } \\
(\mathbf{g})\end{array}$ & $\begin{array}{c}\text { Charcoal } \\
(\mathbf{g})\end{array}$ & $\begin{array}{c}\text { Bone } \\
(\mathbf{g})\end{array}$ & $\begin{array}{c}\text { Artefactual } \\
\text { Stone (g) }\end{array}$ & $\begin{array}{c}\text { Organic } \\
\text { Material (g) }\end{array}$ \\
\hline 1 & 6.0 & 8.0 & 0 & 0 & 10.1 & 0 & 0 & 0.4 \\
\hline 2 & 12.8 & 17.5 & 0 & 0 & 2.6 & 0 & 0 & 1.2 \\
\hline 3 & 19.7 & 22.3 & 0 & 0 & 1.5 & 0 & 0 & 0 \\
\hline 4 & 26.2 & 19.5 & 0 & 0 & 0.7 & 0 & 0 & 0 \\
\hline 5 & 30.5 & 16.8 & 0 & 0 & 1.5 & 0 & 0 & 0 \\
\hline
\end{tabular}

Saccostrea commercialis

Anadara trapezia 